American Journal of Biochemistry and Biotechnology 5 (4): 196-201, 2009

ISSN 1553-3468

(C) 2009 Science Publications

\title{
Molecular Evidence for the Association of a Strain of Uganda Variant of East African Cassava Mosaic Virus to Symptom Severity in Cassava (Manihot esculenta Crantz) Fields in Togo
}

\author{
${ }^{1}$ K.D. Adjata, ${ }^{2}$ E. Muller, ${ }^{2}$ M. Peterschmitt, ${ }^{3}$ O. Traoré and ${ }^{1}$ Y.M.D. Gumedzoe \\ ${ }^{1}$ Laboratory of Plant Virology and Biotechnology, High School of Agronomy, \\ University of Lome, B.P. 1515, Lomé, Togo \\ ${ }^{2}$ Biology and Genetics of Plant-Pathogen Interactions for Integrated Protection, (CIRAD-UMR BGPI) \\ TA 41/K, International Campus of Baillarguet, 34398 Montpellier Cedex 5, France \\ ${ }^{3}$ Institute of Environment and Agricultural Research, 01 BP 476, \\ Ouagadougou 01, Burkina Faso
}

\begin{abstract}
Problem statement: This study was carried out to demonstrate that the severity of Cassava Mosaic Disease (CMD) in Togo, is not only influenced by synergism between cassava Begomoviruses in presence, but essentially by recombination between the different Begomoviruses infecting cassava. Approach: Foliar samples presenting typical biological features of Begomoviruses infection were collected from cassava and wild infected plants from different regions of Togo and analysed by PCR targeting the Coat Protein (CP). The PCR products obtained from different isolates of two major Begomoviruses species infecting cassava in Togo were then sequenced and compared with the sequenced of the African cassava mosaic Begomoviruses identified to date and available in NCBI GenBank database by phylogenetic analysis. Results: The results indicate that not only the two major Begomoviruses could be in synergistic interaction in infected cassava in Togo as it has been shown between African Cassava Mosaic Virus (ACMV) and East African Cassava Mosaic Virus (EACMV) elsewhere, but could also create recombinants which would be highly interfering in the development of symptom severity in the country. Conclusion/Recommendations: The study confirmed the assumption that the symptom severity in cassava fields in Togo is rather caused by recombination between different Begomoviruses in presence than by synergistic interaction. More investigations should be done to give insight to this founding.
\end{abstract}

Key words: Cassava mosaic disease, phylogenetic analysis, recombinant strain, sequences, synergistic interaction, Uganda variant

\section{INTRODUCTION}

Cassava (Manihot esculenta Crantz) is a staple crop grown throughout Africa and it is the most important source of dietary carbohydrate in subSaharan Africa ${ }^{[1,2]}$. The crop is able to produce acceptable yields even on very marginal soils and in drought conditions, but is susceptible to a number of pathogens and losses to cassava production occur in all areas due to Cassava Mosaic Disease (CMD), caused by various Begomoviruses (family Geminiviridae) transmitted whiteflies ${ }^{[3-6]}$. The severity of the pandemic was attributed to a synergistic interaction between African Cassava Mosaic Virus (ACMV) and a recombinant strain of East African Cassava Mosaic
Virus (EACMV), known as the Uganda variant $(\mathrm{EACMV}-\mathrm{UG})^{[7]}$. It was shown in Cameroon that EACMV-CM was a double recombinant capable of synergism with $\mathrm{ACMV}^{[8]}$. The association of these Begomoviruses recombinants with the severe cassava mosaic disease epidemic was obvious although no explanations for the advantage of the heterogonous combination at the level of their CP genes, over the pre existing homologous association, could be provided.

The aim of this study is to describe the complexity of symptom severity in different cassava production regions of Togo caused by cassava mosaic Begomovirus disease by presenting some biological features of their infection which could be created by intermolecular recombination events.

Corresponding Author: K.D. Adjata, Laboratory of Plant Virology and Biotechnology, High School of Agronomy, University of Lome, B.P. 1515, Lomé, Togo 
Am. J. Biochem. \& Biotech., 5 (4): 196-201, 2009

\section{MATERIAL AND METHODS}

Sample collection and virus isolates: Foliar samples were collected from cassava and wild infected plants (Cassia hirsuta, C. obtusifolia, C. occidentalis, Manihot glaziovii, Pupalia lappacea, Strophantus hispidus and Tetrapleura tetraptera). All these infected plants displayed mosaic, leaf deformation, yellowing and stunting symptoms and were collected from five economic regions of Togo between 2004 and 2005 for suitable molecular analysis.

Extraction of the total DNA: The total viral DNA was extracted from the various foliar samples collected according to plant DNA mini preparation method ${ }^{[9]}$. Fifty $\mathrm{mg}$ of cassava infected leaf tissue was ground in $500 \mu \mathrm{L}$ of Dellaporta extraction buffer $(100 \mathrm{mM}$ Tris pH 8, $50 \mathrm{mM}$ EDTA, $500 \mathrm{mM} \mathrm{NaCl}, 10 \mathrm{mM} \mathrm{2-}$ mercaptoethanol) with pestle in $1.5 \mathrm{~mL}$ microtube and $33 \mu \mathrm{L}$ of $20 \%(\mathrm{w} / \mathrm{v})$ of SDS were added, the mix was vortexed and incubated at $65^{\circ} \mathrm{C}$ for $10 \mathrm{~min}$. Then $160 \mu \mathrm{L}$ of $5 \mathrm{M}$ potassium acetate were added to the extract and vortexed and finally centrifuged $10 \mathrm{~min}$ at $14,000 \mathrm{~g}$. The supernatant $(580 \mu \mathrm{L})$ was transferred to new $1.5 \mathrm{~mL}$ microtube and $350 \mu \mathrm{L}$ of ice cold isopropanol was added, vortexed and centrifuged for $10 \mathrm{~min}$ at $14,000 \mathrm{~g}$ and the supernatant was removed and discarded; the pellet was dried for $5 \mathrm{~min}$ in a Speed-Vac dryer and resuspended in $50 \mu \mathrm{L}$ of RNase A $\left(10 \mu \mathrm{g} \mathrm{mg}^{-1}\right.$ in $10 \mathrm{mM}$ Tris-HCl $\mathrm{pH} 8,1 \mathrm{mM}$ EDTA) and left at room temperature for $30 \mathrm{~min}$. DNA was finally precipitated for $30 \mathrm{~min}$ at $-80^{\circ} \mathrm{C}$ in 2.5 volumes of absolute ethanol in the presence of $0.3 \mathrm{M}$ sodium acetate. The pellet was washed twice in $1 \mathrm{~mL}$ of ethanol $70 \%$, dried for $5 \mathrm{~min}$ in a Speed-Vac dryer and resuspended in $500 \mu \mathrm{L}$ distilled water.

Diagnosis by PCR: Identification of the Begomoviruses in the samples was done by Polymerase Chain Reaction (PCR) amplification using specific degenerate primers targeting the Coat Protein (CP), namely: JSP001/JSP002, JSP001/JSP003 and JSP012/JSP013 which identify respectively ACMV (African Cassava Mosaïc Virus), EACMV (East African Cassava Mosaïc virus) and ICMV (Indian cassava Mosaic Virus) ${ }^{[8]}$. These primers are shown in Table 1: JSP001/JSP002 and JSP001/JSP003 give fragments of 770 base pairs; primer pair JSP012/JSP013, specific to ICMV gives fragments of 702 base pairs.

The negative and positive controls (Table 2) were provided by Dr. Max Schoenfelder of DSMZ (Germany). One of the positive controls for ACMV was provided by Dr. Peterschmitt of CIRAD (France) and was isolated in Côte d'Ivoire.
Table 1: Specific primers used for the identification of ACMV, EACMV and ICMV

\begin{tabular}{|c|c|c|c|c|}
\hline \multicolumn{4}{|c|}{ Primer Sequence $\left(5^{\prime} \rightarrow 3^{\prime}\right)$} & Target region \\
\hline JSP001 & \multicolumn{3}{|c|}{ ATG TCG AAG CGA CCA GGA GAT } & 5' ACMV/EACMV CP \\
\hline JSP002 & \multicolumn{3}{|c|}{ TGT TTA TTA ATT GCC AAT ACT } & 3' ACMV CP \\
\hline JSP003 & \multicolumn{3}{|c|}{ CCT TTA TTA ATT TGT CAC TGC } & 3' EACMV CP \\
\hline JSP012 & & 5' ICMV CP \\
\hline JSP013 & \multicolumn{3}{|c|}{$\begin{array}{l}\text { GTC CAT ATA GGT AAR GTN ATG } \\
\text { CCT GCT CCT TGC TNG CYT ART }\end{array}$} & 3' ICMV CP \\
\hline \multicolumn{5}{|c|}{ Source: Fondong et al. ${ }^{[8]}$} \\
\hline \multicolumn{5}{|c|}{ Table 2: List of used positive controls } \\
\hline \multicolumn{3}{|c|}{ Reference No. DSMZ Origin } & \multicolumn{2}{|l|}{ Description } \\
\hline$\overline{\mathrm{PV}-0421}$ & & Nigeria & \multirow{2}{*}{\multicolumn{2}{|c|}{$\begin{array}{l}\text { ACMV-NG: Cassava infected leave } \\
\text { EACMV: Cassava infected leaves }\end{array}$}} \\
\hline PV- 0423 & & Kenya & & \\
\hline PV-042 & & Sri Lanka & \multicolumn{2}{|c|}{ ICMV: Cassava infected leaves } \\
\hline PV-0872 & 2/ Ca-161 & Cameroun & \multicolumn{2}{|c|}{ EACMV: Cassava infected leaves } \\
\hline
\end{tabular}

The PCR reaction was performed in a volume of $25 \mu \mathrm{L}$ containing $2 \mu \mathrm{L}$ of extracted DNA, 1 unit of Taq Polymerase Extrapol 1 (Euro bio), $1.5 \mathrm{mM} \mathrm{MgCl}$, $100 \mu \mathrm{M}$ of each dNTP and $0.8 \mu \mathrm{M}$ of each primer the reaction buffer provided by the manufacturer. The PCR conditions are as followed: a $94^{\circ} \mathrm{C}$ denaturation step of $2 \mathrm{~min}$ followed by 30 cycles of $30 \mathrm{sec}$ at $94^{\circ} \mathrm{C}, 30 \mathrm{sec}$ at annealing temperature $\left(50^{\circ} \mathrm{C}\right.$ for $\mathrm{ACMV}$ and EACMV and $52^{\circ} \mathrm{C}$ for ICMV) and $1 \mathrm{~min}$ at $72^{\circ} \mathrm{C}$ and then a final elongation step of $10 \mathrm{~min}$ at $72^{\circ} \mathrm{C}$.

Virus isolates sequenced: PCR products obtained from Coat Protein (CP) gene ( $\sim 770$ bp) were sent for sequencing at Grenoble in the Laboratory of Bioanalysis, in the unit of Genome express, Cogenics and submitted to GenBank to be numbered. The CP gene sequences obtained from Begomoviruses isolates occurring in Togo were compared to the GenBank accession numbers of the published cassava Begomovirus CP gene sequences ${ }^{[10]}$. The GenBank sequences used in this study were:

- for ACMV: AY211462, AY211466, AY562421 and AY 562429

- for EACMV: AF259896 from Ivory Coast/Cameroon, AJ717534 from Kenya; AJ006461 from Malawi, AY795985 from Tanzania and AF126804, AF423178 and AY562424 from Uganda

- $\quad$ and for ICMV: AJ314739

Sequence analysis: All sequences for the selected viruses were aligned using the ClustalV method of aligning multiple sequences of BioEdit $7^{[11]}$. Phylogenetic analyses were conducted on matrices of aligned sequences by using the neighbour-joining and bootstrap options of DARWin5. The phylogenetic tree was estimated using the neighbor-joining method ${ }^{[12]}$ with the unweighted pair-group method with arithmetic average (UPGMA) distance matrix (MegAlign 
program). One-thousand bootstrap replications were performed to place confidence estimates on major groups resolved in the tree. The aligned sequences were subjected to the same multiple alignments approaches to detect intermolecular recombination events. Dendrograms were viewed, manipulated and printed by using DARWin5 ${ }^{[13]}$.

\section{RESULTS}

Cassava mosaic Begomoviruses disease and symptoms severity in the fields: Symptom severity caused by cassava mosaic Begomovirus disease in the different investigated regions is various and complex through the expression of the infections (Fig. 1). The percentages of the diseased cassava plants in the prospected regions are as follows: $67.3 \%$ for the Central Region; 55.01\% for the Maritime Region; 56\% for the Plateaux Region; 78\% for the Kara Region and $85 \%$ for the Savannas Region (Table 3). Concerning the severity of the symptoms (note of 4-5) in these regions, the rates are: $13.02 \%$ for the Central Region; $4.9 \%$ for the Maritime Region; $7.58 \%$ for the Plateaux Region; $35.14 \%$ for the Kara Region and $26.66 \%$ for the Savannas Region (Table 4).

Six hundred ninety seven collected foliar samples were analyzed by PCR with degenerate primers specific to ACMV, EACMV and ICMV. Results obtained from this analysis revealed the presence of the three targeted Begomoviruses. The results also revealed that the three Begomoviruses are often in mixed infection with the following rates: $39.45 \%$ in the case of ACMV and EACMV, $1.72 \%$ in the case of ACMV and ICMV, $1.29 \%$ in the case of ACMV, EACMV and ICMV. 22\% of the samples were infected by non identified viruses (in fact all the samples collected in this study present typical symptoms of virus) (Table 4).

Sequence analysis and comparison: Hundred and fourteen sequences of CP gene were obtained from isolates of Togo and two of them were submitted to EMBL Database and numbered. These numbered sequences were: Accession EU155148 for EACMV and Accession EU152125 for ICMV. Sequence analysis and comparison of ACMV, EACMV and ICMV from Togo with all the available nucleotide sequences of Gen Bank EACMV is presented in Table 5.

Phylogenetic analysis: $\mathrm{CP}$ gene sequences were considered for this analysis due to their importance for Begomoviruses replication gene expression ${ }^{[14]}$. The phylogenetic tree was estimated using the neighbor-joining method ${ }^{[13]}$ with the Unweighted Pair-Group Method with Arithmetic average (UPGMA) distance matrix (MegAlign program).

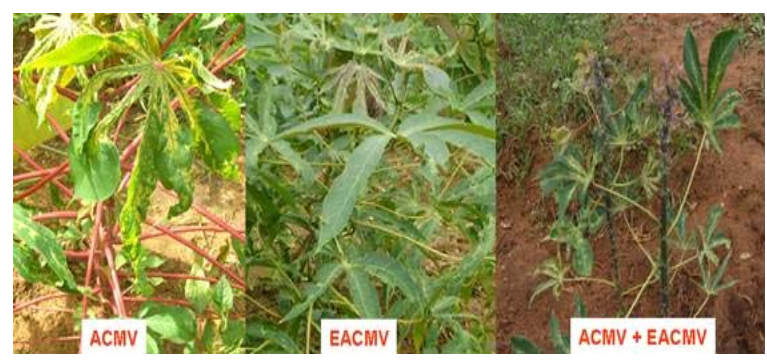

Fig. 1: Various symptoms caused by cassava mosaic Begomovirus disease in the different cassava production areas in Togo: Leaf curling symptom with yellowing caused by ACMV on a local cultivar Yovovi; Leaf curling symptom caused by EACMV on a selected cultivar " $\mathrm{KH}_{1} 04$ " and leaf curling symptom small leaves caused by ACMV in mixed infection with EACMV on a selected cultivar $\mathrm{KH}_{1} 04$

Table 3: Percentages of diseased cassava plants and symptom severity rates

\begin{tabular}{llc}
\hline & $\begin{array}{l}\text { Diseased plants } \\
\text { Percentages }\end{array}$ & $\begin{array}{l}\text { Symptom severity } \\
\text { Rates }\end{array}$ \\
\hline Central & $66.69( \pm 10.75)$ & $13.03( \pm 6.25)$ \\
Kara & $78.17( \pm 8.53)$ & $35.14( \pm 10.37)$ \\
Maritime & $55.25( \pm 17.23)$ & $4.91( \pm 0.77)$ \\
Plateaux & $56.21( \pm 10.56)$ & $7.58( \pm 6.00)$ \\
Savanna & $85.10( \pm 4.10)$ & $26.66( \pm 12.81)$ \\
\hline
\end{tabular}

Note: In bracket, the standard deviation

One-thousand bootstrap replications were performed to place confidence estimates on major groups resolved in the tree (Fig. 2 and 3). From the information we had on the trees, sequence identity was calculated; the criteria utilised to distinguish between different viruses were; $90-100 \%$ for isolates, $80-90 \%$ for strains and less than $80 \%$ for species demarcation ${ }^{[10]}$, due to the number of genetic recombination now known to occur among cassava Begomoviruses. The $\mathrm{CP}$ gene sequences of all the isolates found in our collection were similar to the published sequence of the recombinant EACMV-UG $(96 \% \text { of identity })^{[7]}$.

\section{DISCUSSION}

The results from our field surveys reveal that these viral diseases are present in all the zones of cassava production in Togo. Percentages of cassava plants severely attacked (evaluation note from 4-5) and which could reflect the severity of the disease in the prospected fields vary from one locality to another with the rate of $4.5-36 \%$. This high rate of symptom severity on the plants in the different regions (Table 3 ) could be explained by a possible co-infection by ACMV and EACMV or a recombination between both viruses 
which unusually induces severe symptoms under field conditions $^{[8,14]}$ or by the susceptibility of some cultivars in the prospected fields. This assumption of possible co-infection by ACMV and EACMV which was suspected during our surveys in the different cassava production zones through the severity of symptoms observed was confirmed by the results we obtained by PCR by using degenerate primers specific to the target Begomoviruses infecting cassava. Though ICMV which is known to be present in India was also identified in several cassava production zones; the hypothesis of possible co-infection was also established. The results obtained also reveal that the different Begomoviruses identified are often in mixed infections with the incidence rates showed in Table 4. This founding suggested the possibility that these viruses can act in synergism as it was the case in Uganda $^{[14]}$ and these mixed infections could also incite recombination within the populations of Begomoviruses which infect cassava in this country and could explain the high rate of symptom severity on the plants in the different regions as it was observed during the surveys (Table 3 and Fig. 1).

Table 4: Distribution of ACMV, EACMCV and ICMV in cassava production zones of Togo

\begin{tabular}{|c|c|c|c|c|c|c|c|}
\hline \multirow[b]{2}{*}{ Regions } & \multirow{2}{*}{$\begin{array}{l}\text { Isolates } \\
\text { analyzed }\end{array}$} & \multicolumn{6}{|c|}{ Percentages of Begomoviruses identified in the different regions } \\
\hline & & ACMV alone & EACMV alone & ICMV alone & ACMV+EACMV & $\mathrm{ACMV+ICMV}$ & $\mathrm{ACMV}+\mathrm{EACMV}+\mathrm{ICMV}$ \\
\hline Maritime & 145 & 21.38 & 12.41 & 1.38 & 36.55 & 0.00 & 0.00 \\
\hline Plateaux & 307 & 29.32 & 0.33 & 0.00 & 54.07 & 1.63 & 0.98 \\
\hline Central & 165 & 38.79 & 1.21 & 2.42 & 25.45 & 3.64 & 3.64 \\
\hline Kara & 71 & 36.62 & 7.04 & 1.41 & 16.90 & 1.41 & 0.00 \\
\hline Savanna & 9 & 66.67 & 11.11 & 11.11 & 22.22 & 0.00 & 0.00 \\
\hline Total & 697 & 31.13 & 3.87 & 1.15 & 39.45 & 1.72 & 1.29 \\
\hline
\end{tabular}

Table 5: CP sequences identity (\%) of selected cassava Begomoviruses

\begin{tabular}{|c|c|c|c|c|c|c|c|c|}
\hline \multirow[b]{4}{*}{ Isolats $\mathrm{Du}$ Togo } & \multicolumn{8}{|c|}{ References GenBank } \\
\hline & ACMV & ACMV & EACMV & EACMV & EACMV & EACMV & EACMV & EACMV \\
\hline & AY & AY & $\mathrm{AF}$ & AY & AJ 717534 & AF126804 & AF423178 & AY562424 \\
\hline & 211461 & 526421 & 259896 & 795985 & UG2M & & UGNa & UG2S \\
\hline AC49005M (12-147) & 98 & 97 & 79 & 77 & 93 & 93 & 94 & 93 \\
\hline AC3805K (16-73) & 98 & 97 & 79 & 78 & 93 & 93 & 94 & 93 \\
\hline AC22905P (28-331) & 99 & 97 & 79 & 77 & 93 & 93 & 94 & 93 \\
\hline EAC05-06C (25-149) & 78 & 77 & 96 & 95 & 81 & 80 & 80 & 80 \\
\hline EAC05-30M (30-114) & 78 & 77 & 96 & 94 & 81 & 81 & 81 & 80 \\
\hline EAC05-38K (16-73) & 78 & 77 & 97 & 95 & 80 & 81 & 80 & 80 \\
\hline EU155148 & 94 & 93 & 79 & 77 & 96 & 96 & 96 & 96 \\
\hline
\end{tabular}

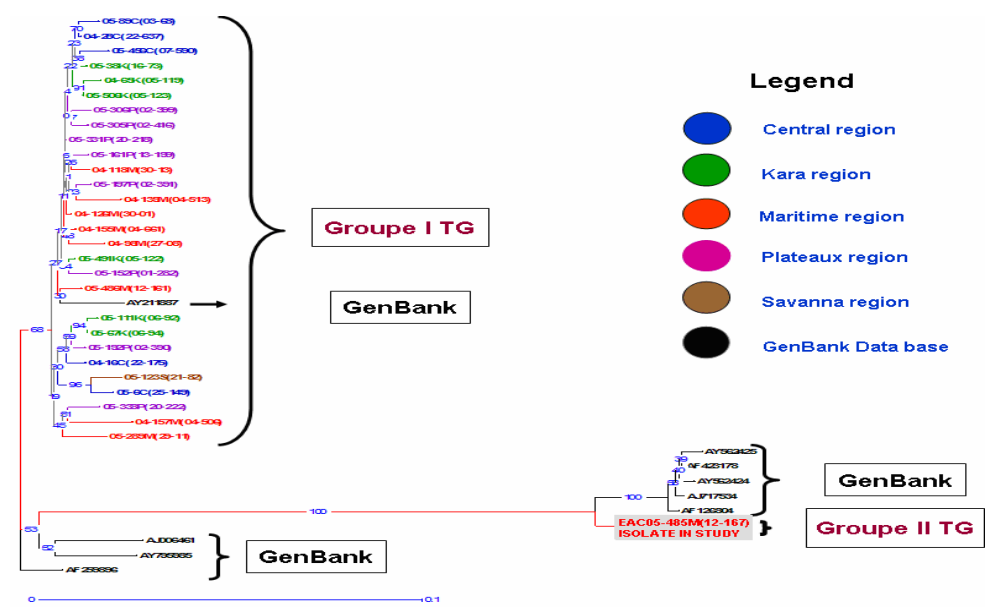

Fig. 2: Consensus phylogenetic tree (10000 bootstrap replications) obtained from comparison of the CP sequences of selected EACMV identified in Togo (black and red bullet) and the GenBank accession number of the published CP Begomoviruses sequences from various part of Africa 


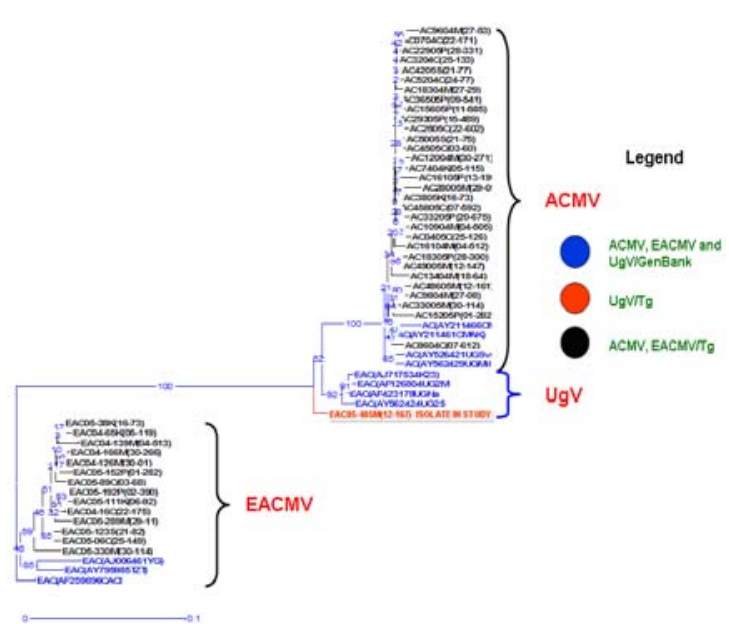

Fig. 3: Consensus phylogenetic tree (10000 bootstrap replications) obtained from comparison of the $\mathrm{CP}$ sequences of selected cassava Begomoviruses occurring in Togo (black and red bullet) and the Gen Bank accession number of the published CP Begomovirus sequences from various part of Africa

Phylogenetic analysis and sequence comparison reveal the evidence of the existence of a recombinant strain between the EACMV and the ACMV in Togo confirming also observations on symptom severity in cassava production areas in Togo and the mixed infections revealed by results obtained from PCR analysis. The CP gene sequence of the isolate found in our collection was similar to the published sequence of the recombinant EACMV-UG ${ }^{[6]}$. These results allowed a better understanding of the severity of cassava mosaic disease nowadays in Togo. It is possible that emergence of new Begomoviruses by recombination may occur in $\operatorname{Togo}^{[15]}$. For some other authors, this type of recombination is known for Begomoviruses ${ }^{[16]}$. The sequence in study was submitted to EMBL Database and numbered (Accession EU155148). Maximum of 96\% sequence identity was obtained with the Uganda variant of EACMV $(\mathrm{UgV})$ isolates in NCBI GenBank. Lower (77-93\%) sequence identity was obtained with other isolates of EACMV which are different from the sequence in study. It is very important to notice that the high degree of molecular variation found among isolate sequences and distinct grouping of isolate sequences was unexpected (Fig. 2 and 3).

The criteria followed to distinguish between different viruses were; $90-100 \%$ for isolates, $80-90 \%$ for strains and less than $80 \%$ for species demarcation ${ }^{[10]}$. Cluster alignments revealed a degree of nucleotide (nt) sequence identity with $96 \%$ identical nt sequences between an accession from Togo, EU155148 and the Uganda variant of EACMV (UgV) isolates in NCBI GenBank. The same accession from Togo, EU155148 compared to other EACMV isolates in NCBI GenBank from various part of Africa like Kenya and Malawi, the sequence identity is $77-79 \%$. But if compared to ACMV isolates in NCBI GenBank, the sequence identity is $93-94 \%$. It is obvious that the accession EU155148 from Togo, is a strain of the Uganda variant of EACMV (UgV) named in our study, the Uganda variant of EACMV from Togo ( $\mathrm{UgV} / \mathrm{Tg})$.

\section{CONCLUSION}

In this study, we demonstrated that the symptom severity caused by cassava mosaic Begomovirus disease on cassava plants in the different regions could not be explained only by a co-infection between ACMV and EACMV but also by a recombination between both viruses which unusually induces severe symptoms under field conditions. This finding is very important due to the new development of the disease in subSaharan region.

\section{ACKNOWLEDGEMENT}

We are grateful to the 'Agence Universitaire de la Francophonie (AUF)' and the 'Service of Co-operation and Cultural Action' for sponsoring this project.

\section{REFERENCES}

1. Lancaster and Brooks 1983. Cassava leaves as human food. Econ. Bot., 37: 337-348. DOI: 10.1007/BF02858890

2. Atiri G.I., F.O. Ogbe, A.G.O. Dixon, S. Winter and O. Ariyo, 2004. Status of cassava mosaic virus diseases and cassava Begomoviruses in the subSaharian Africa. J. Sustain. Agric., 24: 5-35. DOI: 10.1300/J064v24n03_03

3. Legg, J. and C. Fauquet, 2004. Cassava mosaic geminiviruses in Africa. Plant Mol. Biol., 56: 585-599. PMID: 15630622

4. Hong, Y.G., D.J. Robinson and B.D. Harrison, 1993. Nucleotide sequence evidence for the occurrence of three distinct whitefly transmitted geminiviruses in cassava. J. Gen. Virol., 74: 2437-2443. DOI: 10.1099/0022-1317-74-112437

5. Saunders, K., N. Salim, V.R. Mali, V.G. Malathi, R. Briddon, P.G. Markham and J. Stanley, 2002. Characterisation of Sri Lankan cassava mosaic virus and Indian cassava mosaic virus: Evidence for acquisition of a DNA B component by a monopartite Begomoviruses. Virology, 293: 63-74. PMID: 11853400 
6. Dutt, N., R.W. Briddon and I. Dasgupta, 2005. Identification of a second Begomoviruses, Sri Lankan cassava mosaic virus, causing cassava mosaic disease in India. Arch. Virol., 150: 2101-2108. DOI: $10.1007 / \mathrm{s} 00705-005-0579-9$

7. Zhou, X., Y. Liu, L. Calvert, D. Munoz and G.W. Otim-Nape et al., 1997. Evidence that DNAA of a geminivirus has arisen by interspecific recombination. J. Gen. Virol., 78: 2101-2111. PMID: 9267014

8. Fondong, V.N., J.S. Pita, M.E.C. Rey, A. DeKochko, R.N. Beachy and C.M. Fauquet, 2000. Evidence of synergism between African cassava mosaic virus and a new double recombinant geminivirus infecting cassava in cameroon. J. Gen. Virol., 81: 287-297. PMID: 10640569

9. Dellaporta, S.L. J. Wood and H.B. Hicks, 1983. A plant DNA minipreparation: Version II. Plant Mol. Bio. Rep., 14: 19-21. DOI: 10.1007/BF02712670

10. Padidam, M., R.N. Beachy and C.M. Fauquet, 1995. Classification and identification of geminviruses using sequence comparisons. J. Gen. Virol., 76: 249-263. DOI: 10.1099/0022-1317-762-249

11. Hall, T.A. and J.W. Brown, 2002 Archaeal RNase $\mathrm{P}$ has multiple protein subunits homologous to eukaryotic nuclear RNase P proteins. RNA, 8: 296-306. PMID: 12003490

12. Barbara Pickersgill, 2006. Genetic diversity of cultivated tropical plants. Econ. Bot., 60: 91-92. 2006. DOI: 10.1663/0013-0001(2006)60[91: GDOCTP] 2.0.CO; 2
13. Brown, J.K., A.M. Idris, I. Torres-Jerez, G.K. Banks and S.D. Wyatt, 2001. The core region of the coat protein gene is highly useful for establishing the provisional identification and classification of Begomoviruses. Arch. Virol., 146: 1581-1598. DOI: $10.1007 / \mathrm{s} 007050170080$

14. Pita, J.S., V.N. Fondong, A. Sangare, G.W. OtimNape, S. Ogwal and C.M. Fauquet 2001. Recombination, pseudo recombination and synergism of geminiviruses are determinant keys to the epidemic of severe cassava mosaic disease in Uganda, J. Gen. Virol., 82: 655-665. PMID: 11172108

15. Adjata, K.D., E. Muller, M. Peterschmitt, M. Aziadekey and Y.M.D. Gumedzoe, 2008. Incidence of cassava viral diseases and first identification of (EACMV) and Indian Cassava Mosaic Virus (ICMV) by PCR in cassava (Manihot esculenta Crantz) fields East African cassava mosaic Virus in Togo. Am. J. Plant Physiol., 3: 73-80. DOI: 10.3923/ajpp.2008.73.80

16. Padidam, E., S. Sawyer and C.M. Fauquet, 1999. Possible emergence of new geminiviruses by frequent recombination. Virol., 265: 218-225. PMID: 10600594 